\title{
New Religious Movements before Modernity?
}

\section{Considerations from a Historical Perspective}

\section{Andreas Pietsch and Sita Steckel}

\begin{abstract}
Can the study of new religious movements be extended historically towards a longue durée history of religious innovation? Several sociological theories suggest that fundamental differences between premodern and modern religious configurations preclude this, pointing to a lack of religious diversity and freedom of religion in premodern centuries. Written from a historical perspective, this article questions this view and suggests historical religious movements within Christianity as possible material for a long-term perspective. Using the Franciscans and the Family of Love as examples, it points out possible themes for productive interdisciplinary research. One suggestion is to study the criticisms surrounding premodern new religious movements, which might be used to analyze the historical differentiation of religion. Another avenue is the study of premodern terminologies and concepts for religious communities, which could provide a historical horizon for the ongoing debate about the typology of new religions.
\end{abstract}

KEYWORDS: new religious movements, history, new religions studies, societal differentiation, church-sect dichotomy, Middle Ages, Early Modern period, Hendrik Niclaes, Franciscans, Family of Love

Nova Religio: The Journal of Alternative and Emergent Religions, Volume 21, Issue 4, pages 13-37. ISSN 1092-6690 (print), 1541-8480. (electronic). (c) 2018 by The Regents of the University of California. All rights reserved. Please direct all requests for permission to photocopy or reproduce article content through the University of California Press's Reprints and Permissions web page, http://www.ucpress.edu/journals.php?p=reprints. DOI: https://doi.org/10.1525/nr.2018.21.4.13. 
A s sociologist David G. Bromley has suggested, extant horizons of new religions studies might be widened by looking beyond twentieth- and twenty-first-century new religious movements to include historical religious movements. ${ }^{1}$ This idea intrigues the authors of this article, who work as historians of the European medieval era (c. 5001500 C.E.) and the early modern period (c. 1500-1800) respectively, because there can be little doubt that various historical religious innovations closely resemble descriptions of modern new religious movements.

For the medieval period, Francis of Assisi (1181/2-1226) and his followers come to mind. ${ }^{2}$ Having experienced a religious crisis as a prisoner of war, the young Francis rejected the military and merchant careers opened up to him by his well-to-do merchant family and instead embraced radical poverty. He developed an ascetic lifestyle and lived by begging while preaching humility and poverty to others. His charismatic style quickly attracted followers, though it also provoked much criticism. Francis and his early followers unnerved Italian urban elites with highly provocative public performances-Francis notoriously was said to have stripped naked in a public square, dramatically demonstrating his rejection of all worldly belongings. In another instance of apparently senseless behavior, he preached to the birds. Francis' movement, however, soon won papal approval and transformed into the highly successful Order of the Friars Minor (Ordo fratrum minorum, later "Franciscans"), but it continued to meet criticism and resistance. ${ }^{3}$ One point of controversy concerned the order's practice of recruiting promising young men from good families at universities, because the nobility and urban merchant class did not expect sudden religious awakenings from their children. This profile-a charismatic leader, an atypical following, strong antagonism from the secular establishment, and an eventual transformation into an institutionalized structure after the founder's death-fits several characteristics of modern new religious movements. ${ }^{4}$

A lesser-known example of a premodern religious movement will also sound familiar to scholars of new religious movements. The so-called Family of Love (Familists), formed during the second half of the sixteenth century around Dutch merchant Hendrik Niclaes (1501-after 1580), shares a name with the Children of God movement originating with Moses David Berg (1919-1994) in the 1970s, successively renamed The Family of Love and The Family (International). ${ }^{5}$ Other parallels between them are restricted to generic similarities found in many small, highdemand ${ }^{6}$ Christian groups, but these also underline the commonalities between historical groups and more recent movements. Niclaes claimed a form of prophetic authority and assumed the end of the world was near. In order to bring his understanding of the Bible to friends, followers, and larger audiences, he published a large body of religious writings to supplement and explain the message. His teachings emphasized an inward attitude of charity above participation in external, institutionalized rituals 
such as the Catholic Mass. Cultivating an attitude of love, among other things, through readings and meditation would help the believer to reach deification, to become "Godded with God."7

Modern attempts to classify Niclaes' group have tied it to the Radical Reformation (a label which itself has drawn much criticism) or described it as a spiritualist sect. ${ }^{8}$ The Family of Love movement was persecuted repeatedly, and Niclaes had to flee several times to avoid capture. His writings can be found in Emden, Antwerp, Cologne and England, and attracted early translations. ${ }^{9}$ Much like the Franciscans, the group recruited from the urban merchant elite and their scholarly surroundings. Modern research has tried very hard to spot actual members, ascribing membership to high-profile contemporaries such as the scholars Justus Lipsius (1547-1606) and Arias Montanus (1527-1598), and painter Pieter Breughel the Elder (c. 1525/30-1569).$^{10}$

But can such religious innovations of the medieval or Reformation periods really be linked to new religious movements of the twentieth and twenty-first centuries in a manner which, at minimum, will advance theoretical reflection? Are historical religious movements and contemporary new religious movements commensurable in a way that will allow researchers to build a meaningful historical dimension? On one hand, there seems to be a strong prima facie case against this: both early new religions scholars and more recent sociologists have suggested that the dynamics of twentieth-century new religious movements were reactions to specific transformations of modernity. ${ }^{11}$ On the other hand, established religions such as Christianity or Islam were new once, and religious innovations have occurred throughout the centuries.

As there seems to have been little genuinely interdisciplinary exchange between new religions studies and historians of the premodern period on this question, the present contribution seeks to offer some fairly basic considerations and a potential for a historical perspective on new religious movements. To this end, we discuss the problems inherent in current sociological frameworks and give a sketch of previous historical work on religious movements. We then highlight two types of questions and possibly relevant avenues for further research, with a focus on the medieval and early modern history of Christian Europe illustrated by the Franciscans and Familists. We will argue that there are promising areas for exchange between historians and new religions studies scholars. ${ }^{12}$

\section{TYPOLOGIES VERSUS TRANSFORMATIONS: SOCIOLOGICAL AND HISTORICAL MODELS OF LONG-TERM RELIGIOUS CHANGE}

It may be a commonplace in new religions studies to say that established religions were new once, and to point to early Christianity and 
early Islam as examples of successful new religious movements. But the European Middle Ages in particular still have a reputation as a period of religious stability and homogeneity, and this is mirrored in current social science approaches to religion before modernity.

It is actually instructive to view this impression of premodern Europe historically. A negative view of the medieval Latin-speaking church (eventually called Roman, but not yet Roman Catholic Church) largely began with the polemics of the Protestant Reformation, which were adapted and reformulated during the nineteenth-century confessional battles and church-state debates. ${ }^{13}$ These, in turn, formed the backdrop to the emerging sociological tradition's view of the medieval church as something like nineteenth-century Neo-Thomist Catholicism-a unified, monopolistic, and ultimately monolithic structure. Studies ranging from Ernst Troeltsch's discussion of a "unified religious culture" (religiöse Einheitskultur ${ }^{14}$ to Pierre Bourdieu's theory of the medieval religious field as an almost complete religious "monopoly" 15 have implied that the medieval, papal church was the only homogeneous and inescapable framework for medieval religious attitudes. The indisputably documented religious violence and persecution characterizing the Roman Church formed a powerful anchor to this impression. Within the social science tradition, therefore, the Middle Ages appeared to lack two characteristics essential for the growth of new religious movements during the twentieth century - actual religious diversity and the concept of freedom of religion.

This apparent otherness of the premodern period is strongly reflected in the theoretical foundation of new religions studies linking the movements that formed the core of these studies to specific events, such as the rise of the counterculture of the 1960s-1970s. These have been explained as responses to specific sociocultural dislocations caused by modernization, such as rationalization, secularization, materialism, and loss of community. ${ }^{16}$ Because historical religious innovations developed within premodern societies apparently lacked such triggers of modernity more or less by definition, they appear different and incommensurable.

Recent work within the social sciences has not changed this outlook. Discussions of the nature of modernity, especially secularization theory, have dynamized the view of religion in history considerably. ${ }^{17}$ But the case for a fundamentally different configuration of premodern and modern religion-particularly religious plurality and choice mentioned above-has been forcefully restated by authors such as philosopher Charles Taylor and sociologist Peter L. Berger. Though different in outlook and methodology, their studies postulate that modern attitudes towards religion have been shaped by consciousness of a plurality of religious options (including secular ones), even among people who affiliate with a particular religious community. The premodern mentality allegedly understood its religious beliefs and practices as divine truth 
or unquestionable tradition for which there was little alternative. Religion was thus fate, not choice. ${ }^{18}$

Seen from the perspective of a historian, however, this case looks less hopeless. Sociological approaches typically aim to explain modernity rather than historical times, tending to typify historical periods to establish a contrast of premodern or traditional and modern societies. This process necessarily dehistoricizes and homogenizes different historical periods, lumping them into stage models or even just contrasting states of "premodern" and "modern." Historians of older periods, by contrast, view historical and contemporary societies as related, and argue that we should assume societal transformations of long and short durations, of different speeds, intensities, and types. ${ }^{19}$ Processes that can be viewed as generative of modernity — such as globalization, secularization, or societal differentiation, the growth of religious plurality, and even the establishment of freedom of religion-are, to historians, demonstrable processes of gradual transformation already centuries old during the period of high modernity around $1900 .{ }^{20}$ Importantly, they do not offer univocal points of transition from premodern to modern.

From this perspective, religious diversity and freedom in the past appear limited rather than absent, and the necessarily diverse ways in which related concepts may have been understood must be historicized if we want to be able to study them. Religious diversity during the medieval or early modern period may look much unlike modern religious pluralism (see article by Johannes Wolfart in this issue), ${ }^{21}$ but it existed. Though the present article does not attempt to discuss this, both medieval and early modern historians would insist that contact between different religions or religious observances was prominent in some regions of Europe throughout its history, even if that contact was actively battled in others. ${ }^{22}$ While we cannot assume religious freedom, nevertheless religious decisions were made, including decisions for new groups such as the Franciscans and Familists, at times in the face of persecution. Within a specific framework, medieval historian John van Engen has spoken of late medieval religiosity as a world of "multiple options," 23 showing the need to historicize cultural phenomena such as forms of choice and decision-making rather than reduce history to a single transition from non-pluralist to pluralist religion.

\section{“RELIGIOUS MOVEMENTS" IN HISTORICAL STUDIES}

As far as we can see, historical religious innovations have on occasion been discussed within new religions studies and the sociology of religion, but most studies have focused on early Christianity rather than medieval and early modern religious groups. ${ }^{24}$ Some, like John A. Saliba's overview, ${ }^{25}$ simply give compressed historical examples to establish that 
modern new religious movements are not historically unprecedented or abnormal. Probably because of their perceived similarities to "sectarian tradition groups" of modernity, ${ }^{26}$ the focus has been on heretical groups often called sectae (Latin, "sects") by medieval authors. On the historical side, the record of interdisciplinary engagement is even thinner. Although since 2009 Michael Driedger has called for a reception of new religions studies among historians, ${ }^{27}$ extant historical work does not (yet) seem to have taken research on modern religious movements into account. While the term "religious movements" is established in historical studies, it builds almost completely on definitions of social movements. Two publications relating to medieval and early modern history-Herbert Grundmann's Religious Movements in the Middle Ages, and C. John Sommerville's “Interpreting Seventeenth-Century English Religion as Movements" — can illustrate important tendencies.

Within medieval European history, the term "religious movements" is used frequently but remains closely associated to the 1935 study popularizing it, "Religious Movements in the Middle Ages," by German medievalist Herbert Grundmann (1902-1970). ${ }^{28}$ Grundmann dealt mainly with first-generation movements of the twelfth and thirteenth centuries, in which laypeople, or religious virtuosi of various stripes, expressed discontent with the established structures of the Roman Church and initiated new religious life-forms, often engaging in itinerant preaching or following such preachers, or exploring new forms of communal religious life.

Grundmann's study, hailed as seminal by modern researchers, ${ }^{29}$ was indeed much ahead of its time, offering a trenchant critique of typical confessional perspectives and identities shaping the history of medieval religions and, crucially, pointing to the importance of medieval perceptions of religious innovation. ${ }^{30}$ Grundmann showed that observers of the time classed religious movements of the Middle Age as either religious orders or as sects, and modern historians simply followed the path set up by these distinctions. Religious orders typically had been studied by their own members, and their scholarship, though excellent, tended to view their institutional evolution as a gradual realization of the founder's original vision without much consideration of other factors. In contrast, heterodox movements mainly had been studied by Protestant historians who saw them as forerunners of the Protestant Reformation, typically overemphasizing differences between new movements and the established Roman Church, and focusing on doctrinal positions that could be tied to Reformation debates.

In Grundmann's view, attempts to draw these different trajectories together had not succeeded. As he saw it, a "religious movement" (singular) of the twelfth century triggered many successive movements, which either transformed into "orders" or "sects" — not least because outside forces, predominantly the papacy, either integrated, excluded, or persecuted participants. Grundmann drove this point home by comparing two 
groups of radically poor penitents led by charismatic figures around $1200 .{ }^{31}$ One group, associated with Petrus Valdes (c. 1140-c. 1206), came into conflict with ecclesiastical authorities, was branded heretical, and went underground to become the "sect" of the Waldensians. The other, followers of Francis of Assisi, reached an agreement with the pope and, through careful compromises, transformed into a religious order. The latter nevertheless experienced internal conflict that produced what was essentially a new movement with the order, the radical Spiritual Franciscan branch, which Rome eventually persecuted into extinction. ${ }^{32}$

Grundmann offered little in the way of a definition of religious movements. Beyond emphasizing first-generation innovations up to their institutionalization, his understanding of religious movements was shaped by a negative engagement with earlier scholars who, indebted to historical materialism, understood religious movements largely as expressions of social protest. ${ }^{33}$ Against such approaches, Grundmann emphasized the religious nature of innovative movements, at times at the cost of underemphasizing their economic and social contexts. His finding that religious movements were not driven by dispossessed social protesters but by leaders from the nobility and merchant class will be revisited below.

In Grundmann's wake, medievalists use the term "religious movements" as shorthand for the various new religious life-forms of the twelfth and thirteenth centuries 34 _ religious orders, heretical individuals or groups, and their lay followers. But to our knowledge, no further attempt to operationalize the term with reference to new religions studies has been made. ${ }^{35}$

Work on religious movements during the early modern period has typically engaged with the concept of social movements. ${ }^{36}$ A good example is C. John Sommerville's 2000 article on seventeenth-century English "religion as movements," which he defined as "groups organized outside of the normal institutions of a society, to promote social change or to resist it." 37 Sommerville summarized that historians typically find the Weberian/Troeltschian typology of "churches" and "sects" unable to accommodate the broad spectrum of religious innovations and their links to histories of Christian dogma, but that little has been done to remedy this. By understanding religious innovations and transformations as movements, Sommerville expressly hoped to break the mould of older doctrinal history and focus instead on "hopes, goals, programs, and leadership." 38 Drawing on the parallel to social movements, he viewed the movement phase as ending when the group stops its efforts to change society and either retreats into an inward-looking, sect-like existence, or turns into a denomination.

Like Grundmann with his focus on religious orders besides heretical groups, Sommerville emphasized that under premodern conditions, movements could originate within established confessions and churches in particular situations and become reintegrated into them. He offered 
examples comprising a brief case study of the Puritans as a sect-like movement within the larger Protestant context, movement activities among English Catholics (partially in times of persecution and campaigning for acceptance), and finally the movement that reestablished the Anglican Church after the Interregnum (1649-1660). ${ }^{39}$

Extant historical work thus diverges thematically from new religions studies publications that mention historical religious movements, which typically paid less attention to the broad panorama of religious orders and movements within larger confessional churches and focused exclusively on heresies. While this suggests there is space for exploration, there is no clear operationalization of the term "religious movements" for the premodern period-and any such operationalization would indeed have to build on further interdisciplinary exchange.

\section{PERCEPTIONS OF RELIGIOUS INNOVATION DURING THE HIGH MIDDLE AGES (C. 1000-1300)}

Against this background, we return to our central question: Can groups labeled "movements" within premodern history be plausibly linked to new religious movements, and to the theories and methods of new religions studies?

On one side, modern institutional frameworks and perceptions of religious diversity certainly have diverged from premodern ones, and the configuration of the religious field during the twentieth century is quite different from the that of the twelfth or thirteenth century. As observed by Grundmann, the religious landscape in many parts of medieval Europe was characterized by a strong tendency towards religious innovation-but these often sprang from reform impulses and local conflicts rather than contacts between religions (though those could be found, especially in the contact zones of the eastern and western Mediterranean). ${ }^{40}$ Furthermore, religious movements intent on reform and spiritual renewal, or on increased and individualized religious participation for laypeople (not least for women), were often integrated into the institutional structures of the growing Roman Church. This dynamic resulted in a high degree of intra-Christian religious diversity, mainly organized in the form of religious orders - though there was also a sharp wave of persecution that led to the exclusion of many other movements considered "sects" and "heresies."

This process of internal religious diversification continued throughout the eleventh, twelfth, and thirteenth centuries, and coincided with the transformation of the Roman Church into a highly centralized, bureaucratic organization. Taking the role of religious movements into account allows us to nuance the typical older view of the Roman Church as an all-encompassing, unified structure during this period, when the 
church's dynamism and authority encouraged and pursued reforms in several waves, in large part due to its integration of new religious groups. ${ }^{41}$ The papal strategy of integrating some groups while persecuting others allowed a considerable apparatus of control and coercion to grow, and modern views have often focused on the strength of that papacy. Contemporary observers in those centuries, however, perceived a new panorama of religious diversity, not only wary of false prophets and devilish heretics but fascinated and sometimes appalled by the emerging and seemingly never-ending series of new religious life-forms.

At first, debates about the desirability of newcomers broke out within religious and scholarly circles, with members of established orders tending to polemicize against the new movements. English Benedictine monk and chronicler Matthew Paris (c. 1200-1259), for example, questioned the legitimacy of numerous new orders and linked them to the Endtime. ${ }^{42}$ Several proponents of these responded, offering some of the earliest theoretically argued apologies for intra-Christian religious diversity that we possess from the Middle Ages. ${ }^{43}$ Literature aiming for a more general learned audience eventually satirized these debates. In the Latin poetical satire Speculum Stultorum (c. 1180), the monk Nigel de Longchamps (d. c. 1200) ridiculed the fact of each group's insistence that their own ritual observances, diet, or ascetic practices were the holiest, implying that the multitude of groups harmed the overall credibility of religion. ${ }^{44}$

The competition among rival religious orders and pastoral elites (i.e. priests and various orders of canons) also became a matter for church legislators, triggering a legal debate about a "too great diversity of religiones/orders" (nimia religionum diversitas). The Fourth Lateran Council (1215), one of the largest reformation councils of the Middle Ages, banned the founding of further new religious orders, forcing new initiatives to assume one of the extant rules and life-forms. ${ }^{45}$ But even this ruling could not stop debates between and about various orders developing within the newly diversified Roman Church. ${ }^{46}$

Some of the issues surrounding new monastic or mendicant groups were extremely specific and hence may not lend themselves very well to a long-term historical perspective. But in some areas, new religious lifeforms impacted social, political, economic, or legal norms, leading to discussions resembling those around modern new religious movements. The radical poverty of the Franciscans, for example, forced thirteenthcentury laypeople and churches to rethink the issue of the material foundation of religious life, resulting in a veritable torrent of treatises and discussions on the religious meaning of poverty and possessions as well as the connections between religion and the economy. ${ }^{47}$ Many found the Franciscans' extreme contempt for worldly goods exemplary, while others considered their views to be dangerous and the attempt to completely separate religion from social and economic life doomed to 
fail. Absolute poverty was not only quite hard to keep up in practiceafter all, the Franciscans lived in increasingly impressive convents and had funds (though these were nominally owned by others). ${ }^{48}$ Their practice of begging also caused them to be accused of selling absolution from sin. Though their order had some of the harshest restrictions on possessions, they paradoxically came to be accused of greed and mercenary attitudes. 49

Medieval debates about new religious movements concerned their admissibility within the framework of the Roman Church, whereas modern debates focused on the admissibility of such groups within the framework of the nation-state. In both eras, the debated questions-on economic issues, political status, or even gender issues-show at least some parallels. ${ }^{50}$ Which economic practices were admissible for religious groups? Where and how were new groups allowed to proselytize and solicit donations? Were they allowed to recruit at universities, where they at times achieved surprising numbers of conversions? ${ }^{51}$ What leeway was there for women to engage in new forms of religiosity? Did the sexual life of religious group members have to be policed, or could they be trusted to refrain from abuses? 52

Seen in a macro-historical perspective, the issues surrounding medieval religious movements appear as episodes of an ongoing renegotiation of boundaries between religious and political, legal and economic-in other words, an ongoing differentiation of religion and other social spheres. 53

More importantly, medieval religious movements such as the Franciscans not only have been tied to larger transformational processes within historical studies - they have also been viewed in a way that closely parallels the discussion of new religious movements as alternate responses to particular societal dislocations of the twentieth century. The Franciscans, with their ideals of radical poverty, again serve as an especially illuminating example. Though clearly part of a tradition of religious thought, the radical rejection of possessions advocated by Francis also has been read as a response to the growth of a money-based, profit-oriented economy during the twelfth and thirteenth centuries, ${ }^{54}$ especially in Italy with its high degree of urbanization and rising merchant elite. Many Christians considered professional money-making to be despicable, and Francis' rejection not only of possessions but of money itself (which he likened to excrement) was a (rather extreme) reaction to this new monetized economy. In this climate, profit-making urban professions were often viewed as lacking moral legitimacy, precipitating a spiritual crisis among money-makers, ${ }^{55}$ and the quick growth of the Franciscans provided a nostrum for their spiritual fears. The well-to-do merchants and enterprising nobility could support the radically poor (but religiously prestigious) Friars Minor, and thereby offset their money-making by associating themselves with religious poverty as well as profit. As historian 
Lester Little and others have emphasized, this explains the typical profile of the followers of the early mendicant orders already observed by Grundmann: it was indeed the urban elites and nobility, rather than indigent city-dwellers, who supported these religious orders. Eventually, mendicant theologians and lawyers in fact catered more and more to the specific needs of these audiences, for example by developing a more lenient theology that legitimized various profit-oriented economic practices. ${ }^{56}$

As cases like this suggest, medieval religious innovations may at times have been fairly particular-many reform movements within religious orders, for example, apparently were triggered by internal disputes. But other innovations seem to have responded to specific societal developments, thus offering intriguing parallels to modern new religious movements.

\section{CONGEPTUALIZATIONS OF RELIGIOUS COMMUNITY DURING THE EARLY MODERN PERIOD}

A different constellation of religious innovation becomes visible during the later Middle Ages and Reformation period, again offering specific links to the discussion of new religious movements. After the thirteenth century, with a few exceptions, religious innovations could no longer take the shape of new religious orders, and often turned into institutionalized lay religiosity instead. The late medieval movement of the Devotio moderna, which encouraged lay associations engaging in religious reading and meditation, mainly in the Low Countries, represents one of the most important innovations of this kind.$^{57}$ Other broad trends also increased the intellectual mobility of laypeople. ${ }^{58}$ From the high Middle Ages onwards, the Bible was translated into various European languages, along with various adaptations and popularizations of biblical matter. ${ }^{59}$ From the mid-fourteenth century - a full hundred years before the invention of printing with moveable type and the famous Gutenberg Bible-there was a marked increase in lay literacy, which enabled whole new segments of the population to practice an individualized religiosity based on religious reading. ${ }^{60}$ This resulted in an increasing lay demand for religious engagement and caused the formation of many new communities of interpretation uniting lay groups and religious experts. ${ }^{61}$ But in some instances-usually where conflicts acted as catalysts-such local communities could turn into religious movements. Late medieval reform movements such as the English Wycliffites and Lollards and the Czech Hussites belong in this category, ${ }^{62}$ together with some of the movements making up the European Protestant Reformation and the Catholic (Counter-) Reformation. ${ }^{63}$

As the religious upheaval of the period shows, the Roman Church failed to integrate the wave of consecutive innovations, and the intensity 
and impact of transformations increased considerably during the first half of the sixteenth century. The result was a far-reaching fragmentation of the European religious landscape, which became divided into areas and territories in which lay rulers and magistrates emerged as the main guarantors of religious stability. ${ }^{64}$ Over the course of the sixteenth and seventeenth centuries, this led to the consolidation of several new churches besides the entity now calling itself the Roman Catholic Church, often coinciding with political territories or emerging nation states. Smaller religious groups appearing alongside and after the more successful reforming movements were integrated into the already heterogeneous landscape in a more localized fashion. Persecution forced many of these smaller groups into migration or exile, which often transformed them into supranational networks at least partially existing in covert, "underground" shape. ${ }^{65}$

While this panorama was much different from any twentieth-century constellation, it has a specific genealogical or "archaeological" connection to modern research. The fragmentation of the European religious landscape in the sixteenth and seventeenth centuries spawned debates that revisited medieval clashes over the boundaries between religion and secular power while raising fundamental questions about the respective roles of the individual and mediating experts-members of the clergy, but also religious virtuosi-in the quest for salvation. This led to reconceptualizations of religious community — such as a new emphasis on the dichotomy of "church" and "sect" — which became the basis for most further conceptualization and terminology of the academic study of religions, to be revisited with the emergence of the disciplines of history of religions and sociology of religion during the nineteenth and twentieth centuries. ${ }^{66}$

The terms "church" and "sect" long continued to carry the associations given to them during the Reformation battles. Though many emerging sixteenth-century "churches" were actually rather small affairs, and some hereticized "sects" were popular mass movements, contemporary polemics tended to insist that the embattled churches were in fact universal and large, while non-dominant groups were small bands of deviants acting in illegitimate secrecy. As Michael Driedger has warned, we are still haunted by revised versions of this opposition, for example in the twentieth-century concept of the Radical Reformation, which intended to make a place for non-dominant groups within Reformation history but mainly managed to marginalize them. ${ }^{67}$

On one hand, this situation again drives home the otherness of premodern religious constellations in which religious groups' selfconceptualizations would bear little resemblance to modern churches coming to see themselves as coexisting denominations. ${ }^{68}$ On the other hand, the aporia of a decades-long clash of universalisms proved productive for the reconceptualization of religious communities. While established and politically secure communities did not and could not understand 
themselves as denominations during the early modern period, some of the more embattled groups developed concepts that allowed them to claim the status of a universal church even in the face of small numbers and pressing competition. The core group of the Reformed congregation of the young Dutch Republic, for example, notoriously only comprised around twenty percent of the population. ${ }^{69}$ Yet this minority position was compensated by a minority ecclesiology that envisaged the possible number of future elect as small in any case. ${ }^{70}$

The fairly small-scale religious movement of the Family of Love, discussed in the introduction, shared an even more intriguing ecclesiology with other isolated actors along the Dutch/German border. Hendrik Niclaes developed the idea that the invisible church of the elect was made up of the truly charitable, who could be found among the pious members of all churches, and even among non-Christians. ${ }^{71}$ His contemporary and critic Dirck Volkertsz Coornhert (1522-1590) similarly imagined an orthodox community he called "algemeen (common) catholic."72 These reconceptualizations were intriguing attempts to transcend contemporary distinctions of "church" and "sect," and to undermine dominant groups" attempts at clear demarcation. ${ }^{73}$

Niclaes' ecclesiology in particular was tailored to the specific needs of non-dominant religions, allowing them to evade persecution and avoid the despised labels of hypocrisy and dissimulation. He encouraged participation in traditional worship organized by dominant churches as a useful religious exercise for beginners, while individuals with higher aspirations were exhorted to engage in more interiorized spiritual practices_combining Niclaes' new canonical texts, meditation, and spiritual pilgrimages - that promised eventual deification of the believer. This allowed members to maintain their allegiance to the locally dominant church while constructing their own individual, highly elitist way to salvation.

The strong emphasis on individual religiosity in such contexts is a particularly interesting feature of Familist religious practice, and again serves to give an idea of the early modern roots of modern concepts. Intriguingly, Familists cannot be neatly fitted into typologies of "worldaffirming" and "world-rejecting," or "adaptive" and "transformative" religious movements, which have been suggested for twentieth-century new religious movements. ${ }^{74}$ Primarily, the original Family of Love around Hendrik Niclaes appears to have been a close-knit community emphasizing a shared attitude of love and charity. Niclaes personally represented himself as a prophet and paterfamilias (the male head of family) who invited followers to become part of a small, family-like community of the truly elect. All this would render this group a "transformative" and worldrejecting movement. Three Familist manuscripts from the founding generation seem to indicate that such a community was indeed realized at one time, probably during the heyday of Niclaes' own activities. ${ }^{75}$ 
However, the persecution endured by Niclaes and his followers, as well as his own conviction of the meaninglessness of confessional divides, prompted him to adopt an extremely ambiguous, transconfessional style of piety. His printed works - ranging from voluminous doctrinal compendia such as the Glass of Righteousness to shorter, catechetic works and even primers for young believers-at times spoke to the reader in the voice of an inspired prophet, but also simply as a wise father or adviser. Refraining from insisting on his own authority, Niclaes published under a religiously charged cryptonym-HN-denoting the synthesis of the Old and New Testaments (as Helie Nazarenus, Elijah of Nazareth) or a holy nature (hillige natuere). His works often seemed to offer no more than a series of biblical passages put in the service of his own argumentation. In this at-times almost anonymous fashion, he exhorted readers to accomplish a spiritual ascent to deification on their own initiative, fulfilling their divine potential by cultivating, with the help of readings and meditations, an attitude of love and charity. According to Niclaes, the means necessary to do this were strictly in the hands of the readers, with no further external help necessary. In stark contrast to the group's apparent insistence on collectivity and community, this aspect is strongly reminiscent of a "world-affirming" or "adaptive" religious movement that focuses on realizing an individual's divine potential.

A large number of individuals seem to have owned Niclaes' books but had no demonstrable ties to his group. This is especially true of artists, scholars, and courtiers-such as Flemish philosopher Justus Lipsius (1547-1606), Spanish priest and Bible translator Arias Montanus (1527-1598), and even Elizabeth I of England (1533-1603), who have been among the most studied potential Familists. ${ }^{76}$ Older research had a strong tendency to engage in rather wild, ultimately futile speculation on whether these persons were Familist "members." But the "world-affirming," individualist quality of Familist religious practice opens up another way of imagining their relation to the movement. They may have had tenuous or no ties at all to the core group of Niclaes' disciples-in many cases, we simply cannot know. But their possession of the books suggests they were readers of Familist texts, and they may have engaged in the recommended individualized religious practices even without associating themselves closely with the group. In terminology developed by sociologists Rodney Stark and William Sims Bainbridge to categorize modern religion, ${ }^{77}$ the Family of Love may have worked as an "audience cult" whose patrons read canonical texts but made no strong commitment to the group. Such engagement was facilitated by Niclaes' himself, who textualized his own charisma so completely as to become replaceable by his writings.

While this must remain speculation as well, such a profile would explain a peculiarity of the Familist textual tradition. Though we know nothing about the group's organization after the second generation 
disintegrated, and though a later revival in England seems to have had only tenuous connections to the continental origins, the Familist texts were translated and reprinted in several waves on the continent-up to and including the late seventeenth and early eighteenth centuries. ${ }^{78} \mathrm{By}$ that time, however, Familist beliefs had been appropriated and adapted by new religious movements, primarily Pietist circles. ${ }^{79}$

Eighteenth-century Pietist groups are well known for their emphasis on individualized religiosity, and have often been called instrumental in the turn towards the more privatized, individualized form of religion that characterized modernity. ${ }^{80}$ As their reception of the Familist texts shows, however, this religious individualism had a specific prehistory. In the case of Niclaes, the move towards a highly individualized religious practice seems to have been a result of his own quasi-anonymity, in turn linked to the persecution that forced him to engage in evasive strategies. But the practices he advocated also drew on older forms of individualized devotion; comparable forms of reading and meditation had already been common among late-medieval lay movements in the area, such as the Devotio moderna (Modern Devotion) movement, which encouraged laypeople to form religious communities and engage in individual religious reading from the late fourteenth century onwards. ${ }^{81}$ While some mystical elements contained in Niclaes' writings seem to have drawn their origins from religious orders, practices of domestic religious reading were firmly anchored in medieval and early modern lay religiosity practiced in small communities of family and friends. In the face of violent warfare among diverging confessions and a growing religious polarization of public space, the new individualized religiosity of the Family of Love more or less represented a retreat into the domestic sphere, conceptually revalorized and located above and beyond the confessional divisions. Niclaes' curious self-presentation as a divinely authorized but largely only textually present paterfamilias was tailored to fit this social context exactly. ${ }^{82}$ While modern religious individualisms have taken shape in rather different social contexts, such links between specific historical constellations of public and private religion at least invite further reflection.

\section{CONCLUSIONS: \\ GLIMPSES OF A LONGUE DURÉE OF RELIGIOUS INNOVATION}

Overall, we argue that a historical perspective on new religious movements seems not only promising but theoretically sound. The lack of indepth engagement with new religions studies by historians seems largely due to perceived links between new religions studies and late modernity, and consequent references to sociological theories of modernization and pluralization tend to misrepresent the religious diversity of premodern 
Europe. The discussion of extant historical work shows, however, that the typical assumption made within new religions studies that historical religious movements largely consisted of heterodox groups, i.e. persecuted "sects" that can be discounted as marginal, tells only half the story. It omits a rich landscape of intra-Christianity diversity and a number of movements developing within confessional churches. Moreover, the premodern polemicist insistence that all "sects" were small and therefore marginal cannot stand against the historical perspective, which points to several periods of great religious upheaval during which religiosity as a whole seemed fluid and complex to contemporaries. If we discount such historical innovations because they were largely built on intra-religious diversity and thus do not correspond to the modern legal definition of religions/religious groups, we ignore premodern perceptions of diversity and preclude important avenues of investigation.

Instead of postulating a one-step historical transition from premodern, uniform religion to modern religious pluralism after 1800, a cultural history perspective frames the transformation of religion over the centuries as a continuous, though non-linear, process in which the understanding of religiosity, as well the links and differences between religion and other spheres, such as law, politics, and the economy, were repeatedly renegotiated in different regions. ${ }^{83}$ Such a historical perspective would be compatible with the assumption that religious innovations tend to be closely entwined with, or play a part in, larger societal processes. Admittedly, the processes and sociocultural dislocations that can be linked to historical new religious movements (in our examples, the monetarization of the economy during the twelfth century, or the religious fragmentation of the sixteenth century) do not always appear identical with the processes cited for the twentieth century. But these were derived from a modernization theory, which has in any case come under scrutiny and might also be reformulated. The emergence of a functional differentiation of society can, for example, be dated to ancient, medieval, or modern times depending on the definition of "societal differentiation." 84

Some (though by no means all) medieval and early modern religious groups might therefore profitably be studied as historical new religious movements. In exploring how historical actors conceived legitimate and illegitimate religion and discussed its links to economic, political, or gender norms, scholars and historians of modern new religions might be able to contribute to the debate about the sociocultural significance of new religious movements for specific societies. On a different but related trajectory, it might be worthwhile to return to conceptualizations of individual and religious community developed in various historical contexts. While much has been written about the successive rise to prominence of various new terms for religious traditions and groups from the 1850s onward-"religion" and "world religions," 85 then "cult" 
and "new religious movement/new religion"-earlier historical periods show that the sequence of terminological shifts reaches far back. While cultural encounter during the twelfth century saw the rise of lex (law) as a shared term for Christianity, Islam, and Judaism, ${ }^{86}$ the thirteenth century and later Middle Ages saw copious but little-studied use of religio, especially in the plural religiones, for religious orders and lay piety. ${ }^{87}$ During the sixteenth century, the concepts of "confession" and of "church" and "sect" became focal points. ${ }^{88}$ Such reconceptualizations of religious community, coupled with very specific practical contexts, also led to consecutive reinterpretations of the religious agency of the individual. On this issue, which appears particularly close to the selfdefinition of new religions studies, a historical perspective might indeed widen the horizon of current debates.

\section{ENDNOTES}

${ }^{1}$ David G. Bromley, "The Sociology of New Religious Movements," in The Cambridge Companion to New Religious Movements, eds. Olav Hammer and Mikael Rothstein (Cambridge: Cambridge University Press, 2012), 26.

${ }^{2}$ For Francis of Assisi, see Augustine Thompson, Francis of Assisi: A New Biography (Ithaca, NY: Cornell University Press, 2012); and Michael J. P. Robson, ed., The Cambridge Companion to Francis of Assisi (Cambridge: Cambridge University Press, 2012).

${ }^{3}$ Cf. G. Geltner, The Making of Medieval Antifraternalism: Polemic, Violence, Deviance, and Remembrance (Oxford: Oxford University Press, 2012); and Penn R. Szittya, The Antifraternal Tradition in Medieval Literature (Princeton, NJ: Princeton University Press, 1986).

${ }^{4}$ Cf. Eileen Barker, "Perspective: What Are We Studying? A Sociological Case for Keeping the 'Nova,'” Nova Religio 8, no. 3 (July 2004): 88-102.

5 Cf. J. Gordon Melton, The Children of God: "The Family" (Salt Lake City, UT: Signature Books, 2004).

6 A "high-demand" religious group requires strict observance by or obedience from its members in order to join or remain in good standing with the group.

7 See Alastair Hamilton, The Family of Love (Cambridge: James Clarke \& Co., 1981); Jean Dietz Moss, “Godded with God': Hendrik Niclaes and His Family of Love," Transactions of the American Philosophical Society 71, no. 8 (1981): 1-89; also see the pioneering study by Heinrich Nippold, "Heinrich Niclaes und das Haus der Liebe: Ein monographischer Versuch aus der Secten-Geschichte der Reformationszeit [Henry Niclaes and the House of Love: A Monographic Essay on the History of Reformation-Period Sects]," Zeitschrift für historische Theologie [Journal for Historical Theology] 32 (1862): 323-402, 473-563.

8 Cf. George Huntston Williams, The Radical Reformation (Kirksville, MO: Truman State University Press, 2000). On the criticism, see e.g. Hans J. Hillerbrand, "Radicalism in the Early Reformation: Varieties of Reformation in Church and Society," in Radical Tendencies in the Reformation: Divergent 
Perspectives, ed. Hans J. Hillerbrand (Kirksville, MO: Truman State University Press, 1988), 25-41.

${ }^{9}$ For the catalogue of his works, cf. Alastair Hamilton, The Family of Love I: Hendrik Niclaes (Baden-Baden: Koerner, 2003).

10 Hamilton, The Family of Love; and Nicolette Mout, "Faked Conversions? The Case of Justus Lipsius (1547-1606)," in Les modes de la conversion confessionnelle à l'époque moderne. Autobiographie, altérité et construction des identités religieuses [Modes of Confessional Conversion in the Modern Period: Autobiography, Alterity and Construction of Religious Identities], eds. Maria-Cristina Pitassi and Daniela Solfaroli Camillocci (Florence: Leo S. Olschki Editore, 2010), 87-109.

11 David G. Bromley, "New Religious Movements," in Encyclopedia of Religion and Society, ed. William H. Swatos, Jr. (Walnut Creek, CA: Altamira Press, 1998), available at http://hirr.hartsem.edu/ency/NRM.htm, accessed 18 November 2017. Bromley gives a summary of early research views of new religious movements as a reaction to modernity-including Steven M. Tipton, Getting Saved from the Sixties (Berkeley: University of California Press, 1982); and Roy Wallis, The Elementary Forms of New Religious Life (London: Routledge, 1984). Among sociologists, see Robert N. Bellah, "New Religious Consciousness and the Crisis in Modernity," in The New Religious Consciousness, eds. Charles Y. Glock and Robert N. Bellah (Berkeley: University of California Press, 1976), 333-52. For later work assuming a specifically modern new form of religious disintegration, see Pierre Bourdieu, "La dissolution du religieux [The Dissolution of the Religious]," in Choses dites [Things Said] (Paris: Editions de Minuit, 1987), 117-23. Or, assuming a specific lack of religious plurality and dynamism during the premodern period, see Peter L. Berger, The Many Altars of Modernity: Toward a Paradigm for Religion in a Pluralist Age (Boston: De Gruyter, 2014).

12 As space is limited, we unfortunately cannot explore the considerable potential that engaging with new religions studies might hold for historians.

13 See the overview in Andrew Holt, "Historical Studies," in Handbook of Medieval Studies: Terms-Methods-Trends, ed. Albrecht Classen, vol. 1 (Berlin: De Gruyter, 2010), 641-43; on nineteenth-century views of Catholicism, cf. Manuel Borutta, Antikatholizismus: Deutschland und Italien im Zeitalter der europäischen Kulturkämpfe [Anti-Catholicism: Germany and Italy during the Epoch of European Culture Wars] (Göttingen: Vandenhoeck \& Ruprecht, 2009).

${ }^{14}$ Cf. Ernst Troeltsch, The Social Teaching of the Christian Churches, vol. 1 (Louisville: John Knox Press, 1992), 29-30.

15 Pierre Bourdieu, "Genesis and Structure of the Religious Field," Comparative Social Research 13 (1991): 26.

16 See Hamilton, The Family of Love, and Mout, "Faked Conversions?" From the historical side, see Hugh McLeod, The Religious Crisis of the 1960s (Oxford: Oxford University Press, 2007). For a recent approach criticizing and refomulating this link in reference to the work of Anthony Giddens, see Lorne L. Dawson, "The Sociocultural Significance of Modern New Religious Movements," in The Oxford Handbook of New Religious Movements, ed. James R. Lewis (New York: Oxford University Press: 2004), 68-98.

17 From the point of view of new religions studies, see the overview by Christopher Partridge, "Alternative Spiritualities, New Religions, and the 
Reenchantment of the West," in Lewis, The Oxford Handbook of New Religious Movements, 39-67. For the sociological debate, cf. N. J. Demerath III, "Secularization and Sacralization Deconstructed and Reconstructed," in The SAGE Handbook of the Sociology of Religion, ed. James A. Beckford and N. J. Demerath III (London: SAGE Publications, 2007), 57-80. For historical material, see Philip S. Gorski, "Historicizing the Secularization Debate: Church, State, and Society in Late Medieval and Early Modern Europe, ca. 1300 to 1700," American Sociological Review 65, no. 1 (2000): 138-67; and Karl Gabriel, Christel Gärtner, and Detlef Pollack, eds., Umstrittene Säkularisierung: Soziologische und historische Analysen zur Differenzierung von Religion und Politik [Secularization Debated: Sociological and Historical Analyses on the Differentiation of Religion and Politics], 2d ed. (Berlin: Berlin University Press, 2014).

18 Cf. Berger, The Many Altars of Modernity; and Charles Taylor, A Secular Age (Cambridge, MA: Harvard University Press, 2007). This view is summed up with reference to new religions studies by Partridge, "Alternative Spiritualities," 40-42. 19 See the discussions in Alexandra Walsham, "Migrations of the Holy: Explaining Religious Change in Medieval and Early Modern Europe," Journal of Medieval and Early Modern Studies 44, no. 2 (2014): 241-80; Garthine Walker, "Modernization," in Writing Early Modern History, ed. Garthine Walker (London: Bloomsbury, 2005), 25-48; and Lynn Hunt, Writing History in the Global Era (New York: Norton \& Company, 2014).

${ }^{20}$ See e.g. the contributions in Gabriel, Gärtner, and Pollack, Umstrittene Säkularisierung.

21 Johannes Wolfart, "Increasing Religious Diversity: Historiographical Criticism of a Paradigm," Nova Religio 21, no. 4 (May 2018).

${ }^{22}$ Hans Gerhard Kippenberg, Jörg Rüpke, and Kocku von Stuckrad, eds., Europäische Religionsgeschichte: Ein mehrfacher Pluralismus [History of European Religions: A Multiple Pluralism], (Göttingen: Vandenhoeck \& Ruprecht, 2009). ${ }^{23}$ John van Engen, "Multiple Options: The World of the Fifteenth-Century Church," Church History 77, no. 2 (2008): 257-84.

${ }^{24}$ See e.g. Rodney Stark, The Rise of Christianity: A Sociologist Reconsiders History (Princeton, NJ: Princeton University Press, 1996).

${ }^{25}$ John A. Saliba, Understanding New Religious Movements (Walnut Creek, CA: Altamira Press, 2003), 45-74.

${ }^{26}$ Cf. the distinctions made by David G. Bromley and J. Gordon Melton, "Reconceptualizing Types of Religious Organization: Dominant, Sectarian, Alternative, and Emergent Tradition Groups," Nova Religio 15, no. 3 (February 2012): 4-28.

27 Michael Driedger, "Expanding Our Historiographical Vision," in Grenzen des Täufertums. Neue Forschungen / Boundaries of Anaptism: New Research, eds. Anselm Schubert, Astrid von Schlachta, and Michael Driedger (Gütersloh: Gütersloher Verlagshaus, 2009), 411-16; and Michael Driedger, "Protestantische Heterodoxie als Deutungsproblem: Kategorisierungsversuche zwischen konfessioneller Identitätsfindung und postkonfessioneller Geschichtsschreibung” [Protestant Heterodoxy as a Problem of Interpretation: Categorization between Confessional Identity Construction and Post-Confessional Historiography], in Toleranz und Identität: Geschichtsschreibung und Geschichtsbewusstsein zwischen 
religiösem Anspruch und historischer Erfahrung [Tolerance and Identity: Historiography and Historical Images between Religious Ideals and Historical Experience], eds. Kerstin Armborst-Weihs and Judith Becker (Göttingen: Vandenhoeck \& Ruprecht, 2010), 177-94.

28 Herbert Grundmann, Religious Movements in the Middle Ages (Notre Dame, IN: University of Notre Dame Press, 1995).

29 See Robert Lerner's introduction to Grundmann, Religious Movements in the Middle Ages, xxii.

30 Cf. Grundmann, Religious Movements in the Middle Ages, 1-5.

31 Grundmann, Religious Movements in the Middle Ages, 7, 31-68.

32 On the tensions within the Franciscan order, see Michael F. Cusato, "Francis and the Franciscan Movement (1181/2-1226)," in Robson, Cambridge Companion to Francis of Assisi, 17-33; and on the Spiritual Franciscans, see David Burr, The Spiritual Franciscans: From Protest to Persecution in the Century after Saint Francis (University Park, PA: Penn State University Press, 2001).

33 See the discussion by Lerner in Grundmann, Religious Movements in the Middle Ages, xvii.

34 See e.g. Maureen C. Miller, "New Religious Movements and Reform," in A Companion to the Medieval World, eds. Carol Lansing and Edward D. English (Chichester, U.K.: Wiley-Blackwell, 2009), 211-30. One of the more in-depth discussions of the movement quality of a religious innovation is Helmut Feld, Franziskus von Assisi und seine Bewegung [Francis of Assisi and His Movement] (Darmstadt: Wissenschaftliche Buchgesellschaft, 2007) on Francis of Assisi.

35 But Grundmann's book currently is being re-evaluated by a new generation of medievalists; cf. the planned volume Between Orders and Heresy: Rethinking Medieval Religious Movements, eds. Anne E. Lester and Jennifer Colpacoff Deane (Toronto University Press, expected 2018).

36 See e.g. Robert W. Scribner, "The Reformation as a Social Movement," in Popular Culture and Popular Movements in Reformation Germany (London: Hambledon Press, 1987), 145-74; Hans-Jürgen Goertz, Religiöse Bewegungen in der Frühen Neuzeit [Religious Movements during the Early Modern Period] (Munich: Oldenbourg, 1993), 1; Hans-Jürgen Goertz, Pfaffenhass und groß Geschrei: Die reformatorischen Bewegungen in Deutschland 1517-1529 [Hate of Priests and Public Outcry: The Reformation Movements in Germany 1517-1529] (Munich: C. H. Beck, 1987); and Hans-Jürgen Goertz, The Anabaptists (New York: Routledge, 2003), 8-13.

37 C. John Sommerville, "Interpreting Seventeenth-Century English Religion as Movements," Church History 69, no. 4 (2000): 751, with a definition based on John Wilson, Introduction to Social Movements (New York: Basic, 1973), 8.

38 Sommerville, "Interpreting Seventeenth-Century English Religion as Movements," 749.

39 Similar examples about religious movements within Judaism might be derived from Gerhard Lauer, "Die Konfessionalisierung des Judentums: Zum Prozess der religiösen Ausdifferenzierung im Judentum am Übergang zur Neuzeit [The Confessionalization of Judaism: On the Process of Religious Differentiation within Judaism on the Eve of the Modern Period]," in 
Interkonfessionalität-Transkonfessionalität-binnenkonfessionelle Pluralität: Neue Forschungen zur Konfessionalisierungsthese [Interconfessionality-TransconfessionalityJakubowski-Tiessen, Thomas Kaufmann, and Hartmut Lehmann (Gütersloh: Gütersloher Verlagshaus, 2003), 250-83.

${ }^{40}$ Within Latin Europe, the eastern and western Mediterranean areas, especially Iberia, show a strong pattern of religious contact and coexistence; $\mathrm{cf}$. the literature in David Nirenberg, Neighboring Faiths: Christianity, Islam, and Judaism in the Middle Ages and Today (Chicago: University of Chicago Press, 2014); and Nikolas Jaspert, "Contacts between the Major Religious Traditions during Their Expansion: An Introduction," in Dynamics in the History of Religions between Asia and Europe: Encounters, Notions, and Comparative Perspectives, eds. Volkhard Krech and Marion Steinicke (Leiden: Brill, 2011), 165-76.

41 Besides Grundmann in Religious Movements in the Middle Ages, this process of integrating new groups and energy has been described as a "Reformation" by Giles Constable, The Reformation of the Twelfth Century (Cambridge: Cambridge University Press, 1998).

42 See the texts discussed in Sita Steckel, "Narratives of Resistance: Arguments against the Mendicants in the Works of Matthew Paris and William of SaintAmour," in Thirteenth Century England XV: Authority and Resistance in the Age of Magna Charta, eds. Janet Burton, Philip Schofield, and Björn K. Weiler (London: Boydell \& Brewer, 2015), 157-77.

43 See especially Anselm of Havelberg, Anticimenon: On the Unity of the Faith and the Controversies with the Greeks (Collegeville, MN: Trappist, 2010); and Giles Constable and Bernard S. Smith, eds., Libellus de Diversis Ordinibus et Professionibus qui sunt in Aecclesia [Little Book of the Diverse Orders and Professions Extant in the Church] (Oxford: Clarendon Press, 1972). Cf. Markus Schürer, "Innovation und Variabilität als Instrumente göttlicher Pädagogik: Anselm von Havelberg und seine Position in den Diskursen um die Legitimät religiöser Lebensformen [Innovation and Variability as Instruments of Divine Pedagogy: Anselm of Havelberg and His Position in the Discourses on the Legitimacy of Religious Observances]," Mittellateinisches Jahrbuch [Yearbook of Medieval Latin] 42, no. 3 (2007): 373-96.

${ }^{44}$ Nigel de Longchamps [Nigellus Wireker], Speculum Stultorum [Mirror of Fools], eds. John H. Mozley and Robert R. Raymo (Berkeley: University of California Press, 1960), 76-84.

45 Cf. Conciliorum Oecumenicorum Generaliumque Decreta: Editio critica. II/1: The General Councils of Latin Christendom: From Constantinople IV to Pavia-Siena (8691424) (Turnhout, Belgium: Brepols Publishers, 2013), can. 13.

46 See Geltner, The Making of Medieval Antifraternalism; and Szittya, The Antifraternal Tradition in Medieval Literature.

47 On this debate, see Malcolm D. Lambert, Franciscan Poverty: The Doctrine of the Absolute Poverty of Christ and the Apostles in the Franciscan Order 1210-1323 (London: Franciscan Institute Publications, 1961); Andrew Traver, "The Forging of an Intellectual Defense of Mendicancy in the Medieval University," in The Origin, Development, and Refinement of Medieval Religious Mendicancies, ed. Donald S. Prudlo (Leiden: Brill, 2011), 157-96. 
48 On Franciscan buildings, which were much discussed by contemporaries, see Caroline Bruzelius, Preaching, Building, and Burying: Friars and the Medieval City (New Haven, CT: Yale University Press, 2014).

49 See e.g. Geltner, The Making of Medieval Antifraternalism, 28-43.

50 On the modern debates, see James T. Richardson, "Major Controversies involving New Religious Movements," in Hammer and Rothstein, The Cambridge Companion to New Religious Movements, 44-60.

51 Cf. C. H. Lawrence, The Friars: The Impact of the Early Mendicant Movement on Western Society (London: Longman, 1994), 127-66.

52 On the debates around sexuality in the new mendicant orders, see Sita Steckel and Stephanie Kluge, "Secular-Mendicant Polemics and the Construction of Chaste Masculinity within the Thirteenth-century Latin Church," in Celibate and Childless Men in Power: Ruling Bishops and Eunuchs in the Pre-Modern World, eds. Almut Höfert, Matthew M. Mesley, and Selena Tolino (London: Routledge, 2018), 268-95.

53 As has been argued, the differentiation of religion is one of the most important long-term developments of modern Western societies and constituent parts of secularization. Cf. Detlef Pollack, "Varieties of Secularization Theories and Their Indispensable Core," The Germanic Review: Literature, Culture, Theory 90, no. 1 (2015): 60-79, esp. 67-71. For an adapted version of Bourdieu's field theory that might also be helpful to describe historical differentations of religion, cf. Astrid Reuter, "Charting the Boundaries of the Religious Field: Legal Conflicts over Religion as Struggles over Blurring Borders," Journal of Religion in Europe 2, no. 1 (2009): 1-20; and in more detail, Astrid Reuter, Religion in der verrechtlichten Gesellschaft: Rechtskonflikte und öffentliche Kontroversen um Religion als Grenzarbeiten am religiösen Feld [Religion in a Law-oriented Society: Legal Conflicts and Public Controversies about Religion as Boundary Work on the Religious Field] (Göttingen: Vandenhoeck \& Ruprecht, 2014).

54 Cf. Lester K. Little, Religious Poverty and the Profit Economy in Medieval Europe (Ithaca, NY: Cornell University Press, 1983), esp. 146-71; Barbara H. Rosenwein and Lester K. Little, "Social Meaning in the Monastic and Mendicant Spiritualities," Past and Present 63, no. 1 (May 1974): 4-32.

55 Rosenwein and Little, "Social Meaning in the Monastic and Mendicant Spiritualities," 24-32, esp. 24-25.

56 Little, Religious Poverty and the Profit Economy, 165-71.

57 See e.g. John Van Engen, Sisters and Brothers of the Common Life: The Devotio Moderna and the World of the Later Middle Ages (Philadelphia: University of Pennsylvania Press, 2013).

58 See Sabrina Corbellini, Mart van Duijn, Suzan Folkerts, and Margriet Hoogvliet, "Challenging the Paradigms: Holy Writ and Lay Readers in Late Medieval Europe," Church History and Religious Culture 93, no. 2 (2013): 171-88.

59 Cf. Richard Marsden and E. Ann Matter, eds., The New Cambridge History of the Bible: From 600 to 1450 (Cambridge: Cambridge University Press, 2013); and Eyal Poleg and Laura Light, eds., Form and Function in the Late Medieval Bible (Boston: Brill, 2013). 
60 Sabrina Corbellini, ed., Cultures of Religious Reading in the Late Middle Ages: Instructing the Soul, Feeding the Spirit, and Awakening the Passion (Turnhout, Belgium: Brepols, 2013); and Elisabeth Salter, Popular Reading in English c. 1400-1600 (Manchester: Manchester University Press, 2012).

61 These issues are currently studied in the framework of a European research network, COST Action IS1301. See "New Communities of Interpretation: Contexts, Strategies and Processes of Religious Transformation in Late Medieval and Early Modern Europe," COST Action IS1301, http://costactionis1301.webhosting.rug.nl, accessed 20 November 2017.

${ }^{62}$ The larger late medieval reform movements typically have been studied as "premature" or even "first" reformations; e.g. Anne Hudson, The Premature Reformation: Wycliffite Texts and Lollard History (Oxford: Clarendon Press, 1988); and Thomas A. Fudge, The Magnificent Ride: The First Reformation in Hussite Bohemia (Aldershot, U.K.: Ashgate, 1998). On the dynamics of conflict triggering them, see Olivier Marin, L’Archevêque, le Maître et le Dévot: Genèses du Mouvement Réformateur Pragois, Années 1360-1419 [The Archbishop, the Master and the Devout: Origins of the Prague Reformation Movement] (Paris: Honoré Champion, 2005).

63 On the Protestant Reformation and Catholic (Counter-) Reformation, cf. Diarmaid MacCulloch, Reformation: Europe's House Divided (New York: Penguin, 2004); Ulinka Rublack, Reformation Europe (Cambridge: Cambridge University Press, 2017); Alexandra Bamji, Geert H. Janssen, and Mary Laven, eds., The Ashgate Research Companion to the Counter-Reformation (Farnham, U.K.: Ashgate, 2013).

${ }^{64}$ Cf. Ute Lotz-Heumann, "Confessionalization," in Reformation and Early Modern Europe: A Guide to Research, ed. David M. Whitford (Kirksville, MO: Truman State University Press, 2008), 136-57.

65 Cf. Williams, Radical Reformation; and Martin Mulsow, ed., KriminelleFreidenker-Alchemisten: Räume des Untergrunds in der Frühen Neuzeit [CriminalsFreethinkers-Alchemists: Spaces of the Underground in the Early Modern Period] (Cologne: Böhlau, 2014).

${ }^{66}$ Cf. Hans G. Kippenberg, Discovering Religious History in the Modern Age (Princeton, NJ: Princeton University Press 2002); and Tomoko Masuzawa, The Invention of World Religions, or, How European Universalism was Preserved in the Language of Pluralism (Chicago: University of Chicago Press, 2005). Troeltsch, Social Teaching of the Christian Churches, is a prime example of the rediscovery of historical debates on religious community in sociology.

67 Michael D. Driedger, “Against 'the Radical Reformation': On the Continuity between Early Modern Heresy-Making and Modern Historiography," in Radicalism and Dissent in the World of Protestant Reform, eds. Bridget Heal and Anorthe Kremers (Göttingen: Vandenhoek \& Rupprecht, 2017), 139-61.

68 Political stalemates, however, often forced dominant churches to tolerate competitors, and some urban settings allowed far-reaching toleration policies enabling not only multi-confessional but multi-religious coexistence. See e.g. Jesse Spohnholz, The Tactics of Toleration: A Refugee Community in the Age of Religious Wars (Newark, DE: University of Delaware Press, 2011); David Luebke, Hometown Religion: Regimes of Coexistence in Early Modern Westphalia 
(Charlottesville: University of Virginia Press, 2016); Alexandra Walsham, "Cultures of Coexistence in Early Modern England: History, Literature, and Religious Toleration," The Seventeenth Century 28, no. 2 (2013): 115-37; and Thomas Max Safley, ed., A Companion to Multiconfessionalism in the Early Modern World (Leiden: Brill, 2011).

${ }^{69}$ Cf. Joke Spaans, Haarlem na de Reformatie. Stedelijke Cultuur en Kerkelijk Leven, 1577-1620 [Harlem after the Reformation: Urban Culture and Ecclesiastical Life] ('s-Gravenhage: Smits, 1989), esp. 71-108.

70 Ernst Troeltsch, who already observed that this historical situation defied most typologies, discussed the parallel case of the Geneva Reformed Church in a long problematization of the church-sect dichotomy, underlining the need for a development of the extant typologies. See Social Teaching of the Christian Churches, 576-703.

${ }^{71}$ Hendrik Niclaes, Den Spegel der Gerechticheit [The Mirror of Righteousness] (Antwerpen: Plantin, 1555), e.g. book IV, ch. 29B.

72 E.g. in his 1582 Cruydthoofken [Herb Garden], cf. Henk Bonger, The Life and Work of Dirck Volkertszoon Coornhert (Amsterdam: Rodopi, 2004), 181.

73 Andreas Pietsch, "Messbesuch für Anfänger und Fortgeschrittene: Zur Ambiguität der konfessionellen Zugehörigkeit [Mass for Beginners and Advanced Learners: On the Ambiguity of Confessional Belonging]," in Konfessionelle Ambiguität: Uneindeutigkeit und Verstellung als religiöse Praxis in der Frühen Neuzeit [Confessional Ambiguity: Ambiguity and Dissimulation as Religious Practices during the Early Modern Period], eds. Andreas Pietsch and Barbara Stollberg-Rilinger (Gütersloh: Gütersloher Verlagshaus, 2013), 239-67.

74 See the classifications by Wallis, Elementary Forms of New Religious Life, and David G. Bromley, "A Sociological Narrative of Crisis Episodes, Collective Action, Culture Workers, and Countermovements," Sociology of Religion 58 (1997):105-40.

75 The manuscripts are edited in Alastair Hamilton, ed., Cronica: Ordo Sacerdotis: Acta HN Three Texts on the Family of Love (Leiden: Brill, 1988).

76 On Elizabeth, see Patrick Collinson, "Elizabeth I (1533-1603)," in Oxford Dictionary of National Biography (Oxford University Press, 2004), available at http://dx.doi.org/10.1093/ref: odnb/8636, accessed 4 February 2018; and Antonio Dávila Pérez, "Dos lecturas erróneas (omnis familia/amoris familia y simque/sinque): Consecuencias en la bio-bibliografía de Arias Montano (15271598) y de la imprenta plantiniana [Two Erroneous Readings (omnis familia/ amoris familia y simque/sinque): Consequences for the Bio-Bibliography of Arias Montanus (1527-1598) and the Plantin Press]," Lias: Journal of Early Modern Intellectual Culture and its Sources 30, no. 2 (2003): 299-309.

77 Cf. Rodney Stark and William Sims Bainbridge, A Theory of Religion (New Brunswick, NJ: Rutgers University Press, 1987), 155-95.

78 Cf. Alastair Hamilton, The Family of Love II: Hiël (Hendrik Jansen van Barrefelt) (Baden-Baden: Koerner, 2013).

79 Cf. Lesley Monfils, "Family and Friends: Hendrik Niclaes's 'Low German' Writings Printed in England during the Rise of the Quakers," Quaerendo 32, no. 3-4 (2002): 257-83; Alastair Hamilton, "From Familism to Pietism: The Fortune of Pieter van der Borcht's Biblical Illustrations and Hiël's Commentaries from 1584 
to 1717," Quaerendo 11, no. 4 (1981): 271-301; Alastair Hamilton, "Hiël in England 1657-1819," Quaerendo 15, no. 4 (1986): 282-304; and Christopher W. Marsh, The Family of Love in English Society, 1550-1630 (Cambridge: Cambridge University Press, 1994).

80 Martin Gierl, "Pietism, Enlightenment, and Modernity," in A Companion on German Pietism 1600-1800, ed. Douglas H. Shantz (Leiden: Brill, 2015), 348-92. 81 Little, Religious Poverty and the Profit Economy, 165-71.

82 See the woodcuts in Niclaes' books showing a "housefather" teaching his "children," in Alasdair Hamilton, The Family of Love, I: Hendrik Niclaes (BadenBaden: Koerner, 2013), 125.

83 Cf. the suggestions in Walsham, "Migrations of the Holy," 261-65. On a longterm approach in history, see Jo Guldi and David Armitage, The History Manifesto (Cambridge: Cambridge University Press, 2014), available at http:/ /dx.doi.org/ 10.1017/9781139923880, accessed 20 November 2017.

${ }^{84}$ For example, Bourdieu's field theory treats the fields separately and assumes a differentiation of the religious field since antiquity. See Bourdieu, "Genesis and Structure of the Religious Field," 7. Luhmann's theory hinges on the overall primary differentiation pattern of society and favors modernity. See Niklas Luhmann, Social Systems (Stanford, CA: Stanford University Press, 1995).

${ }^{85}$ Cf. Kippenberg, Discovering Religious History in the Modern Age, and Masuzawa, The Invention of World Religions.

86 Peter Biller, "Words and the Medieval Notion of 'Religion," Journal of Ecclesiastical History 36, no. 3 (1985): 351-69.

87 Michel Despland, La Religion en Occident. Evolution des idées et du veçu [Religion in the West: Evolution of Ideas and Practices] (Montreal: Editions Fides, 1979), 73-167.

88 Lotz-Heumann, "Confessionalization"; Lee Palmer Wandel, "Confessions," in Safley, A Companion to Multiconfessionalism in the Early Modern World, 23-43. 